\title{
Activities in Retirement: Individual Experience of Silver Work
}

\author{
Leena Maxin, Jürgen Deller
}

\begin{abstract}
One consequence of demographic change is a longer average remaining lifetime after retirement. Many people, however, remain able and willing to continue work after reaching the statutory retirement age. Given the predicted shortage of skilled workers in the future, post-retirement activities have the potential to contribute to both organisations and society. This article elaborates the prerequisites for productivity in retirement age and the changed nature of retirement at present. It also quantifies the extent to which activities are continued at retirement age. Paid employment still occurs beyond the applicable retirement age, whereby with increasing age, self-employed persons and assistant family members make up the lion's share of the statistics. An empirical study shows the concrete situation of active retirees and the prerequisites for post-retirement activities. At the explorative level, individual experiences of the transition into retirement, the reasons for and the framework of post-retirement activities, motivational factors in job design, and physical and intellectual demands before and after retirement are characterised. The qualitative data indicate that retirement entails changes towards more flexible structures in everyday life. Decisive reasons for taking up post-retirement activities are the desire to help, pass on knowledge or remain active; personal development and contact with others; and gaining appreciation and recognition. Flexible job design and freedom to make decisions constitute major elements in shaping postretirement working activities. Offering autonomy, skill variety, and task significance is important for the design of post-retirement activities. The paper closes with identifying relevant research fields and the concrete need to take action at individual, organisational, and societal levels. All in all, the transition from working life to retirement should be made flexible enough to do greater justice to the realities of life.
\end{abstract}

Keywords: Older workers · Work Motivation · Retirement $\cdot$ Silver Work · Future of work 


\section{Point of departure}

Current debate on the gradual increase in the retirement age to 67 in Germany, which was decided on in 2007 and has been the subject of controversy since then (Spiegel Online 2010), as well as the discussion on the growing labour force participation rate of 55- to 64-year-olds in recent years (Brussig 2009: 281), shows that society and the labour market have become aware of demographic change. From its current level of roughly 16 million, the number of over 65-year-olds in the German population will increase to over 22 million as early as 2030; approx. 23 million, that is, one inhabitant in three, will be 65 or older in 2050 (Bundesinstitut für Bevölkerungsforschung 2008: 18). At the same time, life expectancy is increasing, leading to a further rise in the remaining lifetime after retirement. According to the German statutory pension insurance scheme (Deutsche Rentenversicherung), men draw a pension for an average of 15.8 years and women for 20.6 years. In 2001, these figures were only 13.8 and 18.9 years, respectively (Deutsche Rentenversicherung 2010: 67). The old age dependency ratio will double in the next 40 years. While there are currently 33 retirees for every 100 persons of working age, there will be more than 60 per 100 in 2050 (Bundesinstitut für Bevölkerungsforschung 2008: 18). This can be expected to present considerable challenges to the German social welfare system and the existing pay-as-you-go system (Moog/Raffelhüschen 2010). According to analyses by Prognos AG, the existing shortage of skilled workers will also continue to grow in all sectors in the coming years. If the present framework persists, there will already be a shortfall of nearly three million more workers in 2015 (Gramke et al. 2009:16). At the same time, however, many people remain able to contribute to the economy beyond the statutory retirement age (Lehr/Kruse 2006: 241) and willing to continue to make use of their productivity: The Federal Institute for Population Research surveyed a representative group of 55- to 64-year-olds in dependent employment, $47.3 \%$ of whom wished to remain in employment after their retirement (Büsch et al. 2010a: 6). In a survey of partially retired employees at one company, two thirds of them could have imagined working for longer (Aleksandrowicz et al. 2009: 2-4).

However, in view of different professional groups with different workload demands, it is necessary to distinguish between the nature and magnitude of continued employment. One indication of these disparities is that the average age of retirement is 60.6, much earlier than the statutory retirement age (Deutsche Rentenversicherung 2010: 68). Moreover, individual differences in work ability become evident even prior to retirement age (I/marinen 2005: 135-136). These differences are what continue to make the group with high ability willing and able to contribute. It is hence a matter of making it "not only desirable, but also possible in objective terms" to continue to work (Naegele/Sporket 2009: 279).

Post-retirement activities possess a vast potential and might help solve the societal problems outlined above: Organisations can remain competitive by countering the shortage of specialists and managers at the same time that the burden on social security systems is reduced. Individuals can also tap a major source of personal well-being and health by remaining in employment and earning a little extra income. However, since not all people possess the requisite physical and intellectual fitness, 
only a specific group of individuals remain active and productive at retirement age. Nonetheless, a considerable degree of "silver work" can be observed (Deller/Maxin 2009: 309).

This paper starts by studying the necessary prerequisites for productivity in advanced age and investigating the current situation that is characterised by changes in the nature of retirement. In order to describe the field of tension between employment and retirement, this paper further quantifies the extent of continued employment following retirement in Germany. It then goes on to describe the concrete situation in which active retirees find themselves, as well as the prerequisites for post-retirement activities, on the basis of an exploratory study. It concludes by identifying relevant fields of research and indicating where action needs to be taken.

\subsection{Productivity at retirement age}

People continue to be productive up to an advanced age (see Börsch-Supan et al. 2009: 54-57; Giniger et al. 1983: 473-474). In some cases it is even possible to observe a larger contribution on the part of elderly workers in comparison to their younger colleagues (see //marinen 2005: 136). In addition, older workers often have more professional experience. Many studies identified a positive connection between professional experience and professional performance (Avolio et al. 1990: 416; McEnrue 1988: 181; Quiñones et al. 1995: 904). "Deficit models" of ageing, by contrast, which presume that intellectual performance generally declines in old age, are considered to have been disproven (Lehr/Kruse 2006: 241). There is no doubt that sensory, cognitive, and motor processes change as people grow older (Yordanova et al. 2004: 358-360). However, crystallized intelligence (the ability to use skills, knowledge, and experience) and fluid intelligence (quickly and flexibly dealing with sensory impressions), for instance, develop differently over the lifespan: The degree of crystallized intelligence can increase once more in old age if the person's life provides favourable conditions and there is no specific brain pathology (Baltes 1993: 589). Laboratory studies, by contrast, show that with increasing age, performance and neurophysiological parameters appear to decline in terms of fluid intelligence, e.g. with reaction tasks (Kolev et al. 2009: 222). When it comes to making a contribution, however, compensating for failing skills with other skills that do not decrease or even increase plays a decisive role (Baltes/Carstensen 1996: 205-208; Lehr 2007: 65-66; Salthouse 1984; Wild-Wall et al. 2009: 302). Additionally, environment and individual lifestyle exert an influence on the development of cognitive performance, so that increasing inter-individual differences are seen in advanced age (Hertzog et al. 2008: 5). These influencing factors hence also affect the development of individual work ability in advanced age (//marinen 2005: 136).

Yet productivity in retirement age is influenced not only by the ability to contribute, but also by the willingness to contribute and the personal life situation of the individual. The importance attached to central aspects of life such as work, family, and health changes in the course of a lifetime (Lehr 2007: 53-55). Younger people (25-34) primarily invest in work, followed by friends, family, and independence. The 
so-called life investment among the elderly (55-84), by contrast, is primarily carried out in families, followed by health and friends (Staudinger 1996: 366). Retention of intellectual skills for the life phase of this group of individuals, who in some cases are far above the standard working age, gains importance (Staudinger/Baltes 1996: 64-65). Work-related motives of younger and older workers aged up to 65 also undergo age-dependent changes (Grube/Herte/ 2008; Stamov-Roßnagel/Herte/ 2010: 896-898). In surveys among workers aged 18 to 64, whereas a linear increase between age and the significance of the motive was shown for the aspects autonomy, significance, creating something lasting, helping, and appreciation, a linear reduction was shown for the aspects influence, career, leisure, and fun and enjoyment (Grube 2009: 102-103). These findings provide information on age-related changes among older workers, but not on the motives of working retirees. For the group of 18- to 64-year-olds, the socioemotional selectivity theory of Carstensen (2006) can also take on particular significance. It states that, as people grow older and have a subjectively perceived shorter remaining lifetime, motives shift towards emotionally significant activities and goals: "... [When] people perceive time as finite, they attach greater importance to finding emotional meaning and satisfaction from life and invest fewer resources into gathering information and expanding horizons" (Carstensen 2006: 1915). In the light of a lifetime that is increasingly perceived as being finite, the focus becomes placed on positive emotions, also, for instance, through positively valued experiences at work. Motivations change when new priorities are set.

North American research on motivation (Kanfer 2009) distinguishes between two forms of work motivation, namely the status of work in general terms (motivation for work) and the motivation for a concrete activity (motivation at work). Kanfer stresses that there is a shortage of empirical evidence that theories of work motivation transfer to a higher age (Kanfer 2009: 87). The methods applied show that the "motivation for work" when people are in middle age and older is more closely linked to the working conditions experienced (Kanfer 2009: 88). The motivation to carry out an activity in retirement can hence arise out of matching the activity with an individual motivation for precisely this concrete activity, but also from a high personal status attached to work in general. Studies on the intention to engage in continued employment in retirement additionally show that post-retirement work appears more likely if work takes on a central status in life ( $\mathrm{Lim} / \mathrm{Ng}$ 1997: 199). Age-related changes in work motivation can also emanate from personal attitude changes in self-concept or values (Kanfer/Ackerman 2004: 451-452). This can lead to a change in the acceptance of working conditions (Kanfer 2009: 86). A change in the values attached to the dimensions of motivational job design (motivation at work) is hence also to be expected for active retirees. Factors that exert an influence on the intrinsic motivation for a concrete task have already been defined in the Job Characteristics Model (Hackman/Oldham 1975); based on this, Morgeson and Humphrey (2006) provide an enlarged, comprehensive concept for the motivational work characteristics.

Individual performance hence depends heavily on the job design (see also Schooler 1999: 243). An appropriate job design can enhance the productivity of 
older workers (Skirbekk 2008: 9). As long-term studies have found out, complex tasks are particularly favourable to retaining intellectual abilities in advanced age, (Schooler et al. 1999: 488-490). This also applies to leisure activities with a high degree of complexity (Schooler/Mulatu 2001: 473). In a survey of 55- to 64-year-old workers, Büsch et al. (2010b: 145) found that more than one quarter of respondents evaluated their subjectively estimated ability to work as high or medium, but their own willingness to work as low. Even in the case of perceived performance ability just before retirement age, demotivating factors in job design may hence contribute to existing performance potential remaining unused in old age. Organisational frameworks may partly lead to these changes in motivation. For both workers and retirees, there appear to be motivators for various tasks, not only for professional ones. Many retirees are in a situation in which they can choose their preferences. We presume that existing performance potential can be accessed by reducing or excluding demotivating factors, as well as by establishing and expanding conditions that enhance motivation in a work environment.

\subsection{A new form of retirement}

The nature of retirement has undergone considerable change over time (for an overview: Shultz/Wang 2011). A new relationship between work, learning, and leisure can be increasingly observed in which these elements are more closely interlinked and exist regardless of age (Reday-Mulvey 2005: 21-22). The term "retirement" used to signify the conclusion of an active working life, and implied that workers withdrew from the labour market altogether. Given the increasing remaining lifetime in retirement, however, many people turn to alternative employment, such as voluntary work, after completing their regular working lives (Alterssurvey 2002a: 5; Freiwilligensurvey 2006: 303-305), but also to continued professional employment (Alterssurvey 2002b: 3; Griffin/Hesketh 2008: 115-117; Ulrich/Brott 2005: 160).

Continued professional employment in retirement has been the subject of research in North America for more than two decades (Doeringer 1990: 5-7; Wang et al. 2008: 818-819). Since then, bridge employment has been registered and analysed as a social phenomenon likely caused to a considerable degree by the needs of the labour market. Whereas elderly workers in the USA and Canada in the 1950s were still able to presume that they would have lasting, long-term employment relationships (see Calo 2005: 302), companies began to push elderly workers into early retirement in the $1980 \mathrm{~s}$. The reasons included increasing competition among organisations, also leading to mergers and take-overs, internal restructuring, and job cuts (see Doeringer 1990: 7-8; Feldman 1994: 286). Since then, a significant number of affected workers consequently participate in different forms of bridge employment (Feldman 1994: 286). Bridge employment refers to tasks that generally entail a combination of reduced working hours, less responsibility, greater flexibility, and less physical strain (Feldman 1994: 287-288). These conditions offer elderly workers the option to gradually withdraw from the labour market (see Shultz 2001: 253; Weckerle/Shultz 1999: 325-326). At the same time, they give elderly workers the opportunity to remain on the labour market beyond retirement without having 
to forego gains in terms of leisure time and self-determination in everyday life. In this context, bridge employment may be taken literally since it offers the individual a bridge between the obligations of full-time employment and complete withdrawal from the labour market into retirement (Beehr/Bennett 2007: 278). Bridge employment activities do not necessarily constitute less demanding or challenging work (Adams/Rau 2004: 720). Managers may, for instance, be available to their former employer in an advisory capacity beyond retirement age or return to the company for individual projects.

The possibilities of employment in the context of bridge employment are manifold. The literature often distinguishes between career bridge employment and bridge employment in a different field, also referred to as non-career bridge employment (see Feldman 1994: 289; Gobeski/Beehr 2009: 409-410; Wang et al. 2008: 818). In the context of career bridge employment, towards the end of their professional careers workers can continue in their original field of work with their previous employer, with another company or on a self-employed basis (see Gobeski/ Beehr 2009: 417). Alternatively, in the context of non-career bridge employment, it is conceivable to choose employment that is unrelated to the job or sector (see Shultz 2001: 252-253). One example of work within career bridge employment is when retired teachers continue their teaching activity in adult education for a charitable organisation. An example of non-career bridge employment, by contrast, is when a postal company employee transports patients as an unskilled worker after reaching the statutory retirement age. Because of the low level of skills required, non-career bridge employment is often poorly paid, which may also entail a loss of status (see Feldman 1994: 289; Gobeski/Beehr 2009: 402). Tasks in the context of bridge employment encompass paid employment or unpaid voluntary work (see Griffin/Hesketh 2008: 102-103). The paid activities can be carried out on the basis of employment or self-employment (see Doeringer 1990: 6). Other alternatives are full-time and part-time work, as well as project and casual work (see Gobeski/Beehr 2009: 401).

Retirement constitutes a radical change in life that is felt to differing degrees by different individuals (Calo 2005: 306; Mayring 2000: 132). There are empirical indications of the change being perceived as less significant in comparison to other life events, but there are major inter-individual differences in this perception (Matthews/Brown 1987: 567). The less rigid structure of daily routine or of relationships with others after retirement can in some cases be regained through activities (Atchley 1989: 188). After a working life entailing a high workload, post-retirement activities can ease the transition into retirement.

Motives for engaging in bridge employment can be distinguished into personal reasons, a desire for contact, or financial and generative reasons (Dendinger et al. 2005: 23-25; Mor-Barak 1995: 332-334). Personal reasons lead to acts that increase one's own well-being. The need to remain intellectually and physically active is essential in this respect to activity in retirement (Brown 2003: 21). Perceived appreciation and recognition of the contribution made, as well as enjoyment of and interest in the activity appear to play a vital role in taking up a paid or unpaid activity after professional employment (AARP 2002: 59). Adapting to retirement can be facili- 
tated by maintaining external structures and previous contacts (Atchley 1989: 183). A desire for contact can also be a major reason for activities in retirement (Aquino et al. 1996: 488). The desire to pass on knowledge and experience to the next generation was identified as a central influencing factor for continued employment in retirement in North America (Calo 2005: 306-309; Dendinger et al. 2005: 31-33; Saba/ Guerin 2005: 208). These generative reasons encompass passing on experience or the desire to help others. Another major requirement for taking up an activity is flexibility (Brown 2003: 10). This includes, for instance, the possibility to take time to care for family members and to be able to determine one's working time oneself.

The transition into retirement is a process that is influenced by personal and environmental factors (Beehr 1986: 46; Feldman 1994: 291; Ulrich/Brott 2005: 163-164). A large number of empirical studies have identified individual preconditions, as well as work- and organisation-related, family-related, and socio-economic factors, as major factors influencing the process of retirement (Wang/Shultz 2010: 182). The various manifestations of the individual transition show either a quantitative and/ or a qualitative deviation from the previous employment, which is expressed in changes in working hours, a new employer, or another type of employment (Pleau 2010: 4). Feldman (1994: 288) identifies as a motivation for retirement the need for a less stringent psychological connection with the world of work. The transition into retirement hence must not necessarily result in complete withdrawal from the labour market and in exclusively drawing pensions. In the sense of bridge employment, retirement can instead be perceived as a further stage in the individual career development (Calo 2005: 307; Wang/Shultz 2010: 179-180) in which persons continue to work on the labour market in a reduced form.

\section{Post-retirement activities in Germany}

In Germany, initial practical models have been developed relating to the use of the professional skills that have been acquired by skilled retirees. These methods are currently exclusively concerned with the imparting of expert knowledge and skills. Organisations complying with the concept of the Senior Expert Service (SES), Bosch Management Support GmbH (BMS), or Erfahrung Deutschland GmbH (ED) place retirees in voluntary (SES) or paid work either within a company (BMS) or without taking former company affiliations into consideration (ED). The existence of these organisations demonstrates that, when suitable frameworks and appropriate skills are available, employment in retirement can be interesting for persons and companies. Because pensions drawn are likely to be lower in the foreseeable future, other forms of employment in retirement may also take on primary significance. For the less highly skilled it will then presumably be more a matter of managing financially than of imparting knowledge.

Since the population of traditional working age is shrinking, attractive framework conditions may be helpful for recruiting workers of all ages. Here, work should be offered in an attractive and suitable form for all population groups. The current paper attempts to take an initial empirical step towards addressing the phenomenon of silver work. We have therefore chosen an exploratory approach here to cover 
as broad a range of subjective estimates as possible. Connected to the research on bridge employment, this approach generates initial findings on the design of silver work in the socio-economical and political environment in Germany, which differs from that in North America. The goal is to arrive at a differentiated depiction of the life reality of this specific group of individuals. This first step will lay a necessary foundation for dealing with this new applied field of research and testing hypotheses in further steps. The approach hence answers Kanfer's (2009: 89) call for targeted research into basic phenomena in "specific samples" if there are only few indications of the empirical validity of established theories in these fields. In order to illustrate the phenomenon of silver work, we first quantify the extent of officially recorded post-retirement work in Germany. We then present the explorative results of a first empirical study, indicating the concrete situation and prerequisites for post-retirement activities in Germany.

\subsection{Extent of post-retirement activities}

Although bridge employment is a widespread phenomenon in North America (Dendinger et al. 2005: 21-22; Doeringer 1990: 6; Shultz 2001: 248; Wang et al. 2008: 818-819), no figures were available until recently on active retirees' labour market participation in Germany.

\subsubsection{Sample and method}

To determine the extent of post-retirement work in Germany, we looked at numbers of persons in paid employment, which are regularly published in the microcensus by the Federal Statistical Office. Although the Federal Statistical Office collects this information on a yearly basis, data for the group aged 65 years and older were reported for the first time for 2007 (Deller/Maxin 2009: 308; Statistisches Bundesamt 2009a).

\subsubsection{Results of the microcensus}

Figure 1 shows the number of persons remaining in paid employment at retirement age for 2007. As anticipated, an ongoing reduction in the number of persons in paid employment can be observed. Whereas at the age of 65, 100,000 persons in paid employment are reported nationally, 11,000 persons are still in paid employment at the age of 75. Furthermore, paid employment is still found in the even older cohorts on a case-by-case basis. Here, however, more precise observations can likely be made only after a new census has been carried out, given that in the microcensus the number of cases in the 75-plus age groups has shrunk to a size for extrapolation is no longer possible (Statistisches Bundesamt 2009b).

One group of particular interest are the self-employed. They form the largest professional group among those in retirement age, their share clearly growing with increasing age (see Fig. 2). Roughly 55,000 self-employed persons are still in paid employment in the age group of 70 to 74 alone. At the same time, professional activ- 
Fig. 1: $\quad$ Persons in paid employment 2007 aged 65 to 75

Absolute figures in 1,000 s

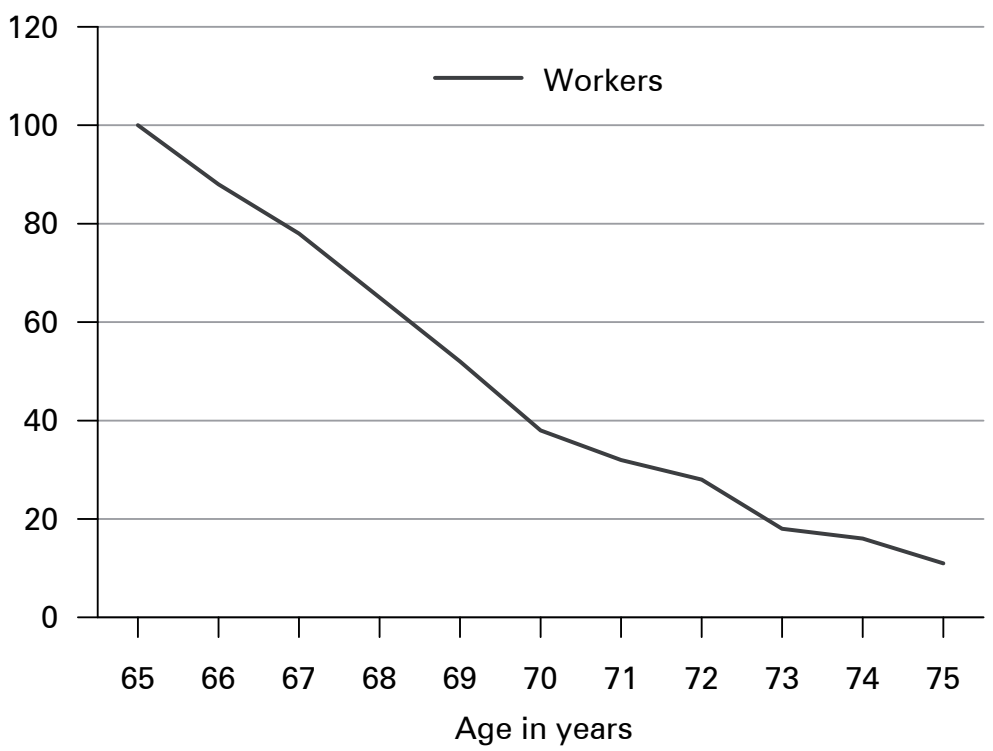

Source: Statistisches Bundesamt 2009a, own design

ity on the part of civil servants in the same age group can no longer be observed. This suggests that pensioners from this group who are interested in continued activities beyond retirement age seek other forms of employment because of the existing restrictions on post-retirement work, possibly in self-employment.

Looking at the percentage of self-employed and of assistant family members among persons in paid employment (Fig. 2), one can clearly observe for both groups a relative increase with rising age. The self-employed account for only $12.4 \%$ of persons in paid employment aged 50 to 54, but for almost half of those aged 75 to $79(47.7 \%)$. If one adds to these numbers the assistant family members helping the self-employed, this group accounts for $65.9 \%$ of all persons in paid employment in the highest age class.

As has been shown, paid employment also exists beyond the applicable retirement age. The number of those currently of retirement age who remain in paid employment per age group sinks with advancing age. However, not all professional groups participate in continued paid employment to the same degree: Whereas former civil servant pensioners aged over 65 do not appear in the statistics as being in paid employment, the dominance of the group of the self-employed increases with advancing age. Other forms of employment in retirement, such as voluntary and family commitment, also play a major role in this age group. Over 60-year-olds currently constitute the largest growth group of voluntary commitment (Freiwilligensurvey 2006: 312-315). In the coming sections we will present the results of a comprehensive study on the life realities of currently paid and unpaid working retirees. 
Fig. 2: $\quad$ Percentage of all professional groups among persons in paid employment of the respective age group in 2007

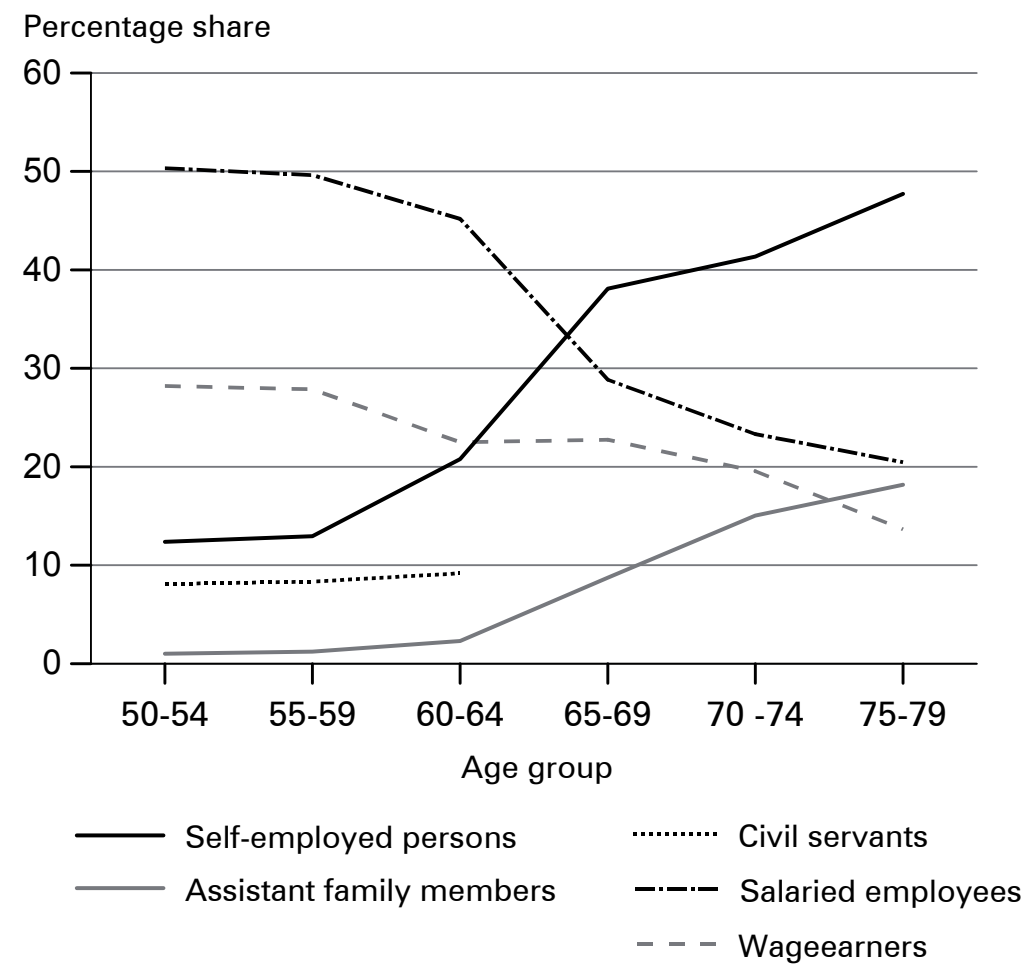

Source: Statistisches Bundesamt 2009a, own design

\subsection{Characteristics of post-retirement activities}

In this section, we present the results of a first empirical study on the formation and manifestation of silver work in Germany.

\subsubsection{Target group}

Taking the point of departure outlined in the first section, this exploratory study aimed to obtain a picture of the individual situation of active retirees in Germany. To this end, we primarily developed open-ended questions, the answers to which were largely left to the respondents themselves in terms of their length and content. We explored some selected aspects on the basis of existing theories with the aid of quantitatively anchored scales. Our sample consisted of silver workers, officially retired persons who continue to engage in one or several paid or unpaid activities (see Deller/Maxin 2008). The reasons for and framework of these activities formed the focus of the explorative and applied survey. Open-ended questions on the transition into retirement and on the design of everyday routines, together with a quan- 
titative comparative survey of the former and current work situations, supplement the semi-structured questionnaire of the survey. In the following, questionnaire and sample are described.

\subsubsection{Questionnaire}

We collected the data with a semi-structured interview guide in the context of telephone interviews lasting an average of 60 minutes. The practical relevance of the questionnaire was ensured in close cooperation with personnel officers from DAX companies and from a consulting firm specialised in evaluating jobs. It was possible to categorise the professional activity of the interview participant prior to retirement using questions on the nature of the job (complexity and responsibility) and the size of the company, using a version of the Hay Group job evaluation system.

The topic of transition into retirement was explored by combining four openended and four closed questions: a) What were your feelings on approaching retirement? b) In overall retrospect: Have you achieved your professional goals (0-150; anchor: 0 -no goal achieved, 50-partly, 100-completely achieved, 150-over exceeded)? c) For what reasons did you retire (at this time)? d) Looking back, would you make the same decision again (Yes/No)? e) How did you find your present activity? f) All in all, have you personally gained more freedom? How important is this to you? (0-100; anchor: 0-not important at all, 50-important but not sufficiently, 100 -indispensable/highly decisive)? g) To what degree are the skills you use today identical to those of your former work (in \%)? h) Please describe the ratio between your work and leisure times: To what degree are these interrelated?

A total of five open-ended questions were asked on the topic of reasons for and framework of post-retirement activities: a) What reasons do you have for working in retirement? b) What is particularly important to you in your work? c) What would be the ideal conditions for work in retirement? d) What should a specific personnel policy for elderly workers look like? e) Where do you see the greatest need for action for firms with regard to the employment of elderly people?

For the depiction of factors of work motivation, we applied a section from the Job Diagnostic Survey of Hackman and Oldham (1975), which describes motivational work characteristics. We selected this method for two reasons: Firstly, we wished, in addition to the open-ended questions, to obtain initial impressions of the distribution of the fundamental factors of work motivation in post-retirement work settings. We therefore asked for an assessment of these motivational work characteristics on a scale from 0 to 100. For this first empirical step, we chose these five basic job dimensions. Only after data collection had started was a comprehensive questionnaire for motivational work characteristics published that also included other dimensions (Morgeson/Humphrey 2006). Secondly, the many open-ended questions left little time for detailed quantitative surveys without going beyond the scope of the telephone interview. The study used a selection of the job dimensions skill variety, autonomy, task significance, task identity, and task-related feedback that contribute to work motivation (Hackman/Oldham 1975; Morgeson/Humphrey 2006: 1323; Oldham/Hackman 2010: 464). Skill variety is understood here as the degree 
to which work requires many varied skills. Autonomy signifies the degree of selfdetermination with which the work is carried out. Task significance is expressed in how important or significant individuals personally consider their work to be. Task identity describes the degree to which the work facilitates the creation of a completed piece of work or project. Task-related feedback signifies the degree to which someone can directly ascertain from the job how well they have worked (Hackman/ Oldham 1975: 161-162; Landy/Conte 2010: 399; Morgeson/Humphrey 2006: 1323). The extent of the existence of these dimensions was assessed on a scale of 0 to 100 at three different points in time (before and after retirement, as well as in an ideal situation).

Physical and intellectual demands were rated on a scale from 0 to 100 with the anchor values 0 -no demands, 50-medium demands, and 100-very high demands. Once again, respondents were asked for an assessment of the current employment situation, a retrospective evaluation of the former work situation, and their ideal of employment in retirement. Additionally, respondents were asked to state up to which age they wished to continue to work (maximum age). With this approach, we would like to gain an approximation of the actual ability of respondents to contribute at three points in their lives. The specific make-up of the sample in this survey (see section 2.2.4) is contingent on motivation, since only retirees who were working beyond the statutory retirement age on their own initiative and of their own accord were surveyed.

\subsubsection{Data analysis}

Quantitative data were analysed using the SPSS 17.0 and Microsoft Excel software programs. The open-ended questions were analysed using content analysis (Mayring 2008; Neuendorf 2002). To this end, the unstructured statements were recorded on tape, transcribed, paraphrased, coded, and quantified in a following stage by inductive category formation (Mayring 2008: 74-76). Wherever the complexity of the dataset allowed, interrater reliabilities according to Krippendorff were determined for the categories of the content analysis (Craggs/Krippendorff 2004; see also Krippendorff 2004: 427-428). Two independent judgments by trained raters were consulted to calculate the coefficient. Semantic validity and construct validity were ensured through multipersonal codebook development in a team of two to six developers, and in some cases through triangulation (Flick 2008: 312-313; Mayring 2008: 111).

\subsubsection{Sample characteristics}

Organisations such as trade unions, charities, or companies were identified that had contact with their former members in retirement, and contacted via e-mail. The goal was to recruit study participants from the white collar field, in which more than $40 \%$ of all those in paid employment in Germany were employed at the time of data collection (BAuA 2008: 6). However, it was not possible to obtain a sufficiently large sample on the basis of this systematic approach because of a lack of cooperation 
on the part of the organisations approached. As an alternative, personal contacts of the research team and recommendations of interview partners were used for recruiting. A cumulative sample was created that does not claim to be representative of the population.

From September to December 2005, as well as from April to July 2006, a total of 146 retirees in paid or voluntary work aged 60 to $85(M=67, S D=4.2)$ were surveyed in telephone interviews lasting an average of 60 minutes. The standard deviation (SD) provides information about the amount of difference in the sample. A high value depicts a large degree of differentiation, and a low value shows a lower degree of differentiation between the individuals surveyed. $31 \%$ of the sample were women and $69 \%$ men. Almost $60 \%$ of the interviewees held a university degree. The sample hence has an above-average level of education.

Information on the interviewees' work prior to retirement made it possible to distinguish between management and non-management functions. Functions lying between these levels cannot be unambiguously determined. Table 1 shows the composition of the sample with respect to the professional position prior to retirement, while Table 2 reveals the field of post-retirement activities. The categorisa-

Tab. 1: Activities of the study participants prior to retirement

\begin{tabular}{|c|c|c|c|}
\hline \multicolumn{2}{|c|}{$\begin{array}{l}\text { Level of complexity } \\
\text { by Hay Group }{ }^{1}\end{array}$} & \multirow{3}{*}{$\begin{array}{l}\text { Spread in the } \\
\text { sample (\%) }\end{array}$} & \multirow[t]{2}{*}{ Example positions } \\
\hline 1 & higher & & \\
\hline & complexity & & \multirow{3}{*}{$\begin{array}{l}\text { State Secretary, } \\
\text { managing director, } \\
\text { board member }\end{array}$} \\
\hline 2 & & 1.4 & \\
\hline 3 & & 0.7 & \\
\hline 4 & & 7.9 & \multirow{3}{*}{$\begin{array}{l}\text { Chemist, head of division, } \\
\text { general in the federal armed services, manager, } \\
\text { professor, chairman of a savings bank, director } \\
\text { of studies }\end{array}$} \\
\hline 5 & & 10.8 & \\
\hline 6 & \multirow{2}{*}{$\begin{array}{l}\text { medium } \\
\text { complexity }\end{array}$} & 12.9 & \\
\hline 7 & & 21.6 & Manager, design engineer \\
\hline 8 & \multirow{5}{*}{$\begin{array}{l}\text { lower } \\
\text { complexity }\end{array}$} & 13.7 & \multirow{5}{*}{$\begin{array}{l}\text { Master baker, banker, driver, teacher, } \\
\text { pastor, office worker, tax official, } \\
\text { technical worker, cleaner }\end{array}$} \\
\hline 9 & & 18.0 & \\
\hline 10 & & 10.1 & \\
\hline 11 & & 0.7 & \\
\hline 12 & & 1.4 & \\
\hline
\end{tabular}

Notes: $\mathrm{N}=139$.

1 Classification of the last full-time position prior to retirement was carried out by the Hay Group. Levels of complexity 1-6 correspond to management functions; levels 8-12 correspond to non-management functions; level 7 cannot be clearly attributed.

Source: own design 
tion of the former professional position (Tab. 1) is based on the information about the interviewees' last full-time employment prior to retirement. $34.4 \%$ of the respondents were employed in management; $43.9 \%$ were not. $21.6 \%$ of the sample worked in the area that was not unambiguously determinable.

The categorisation of the clients of work after retirement (Tab. 2) arose through a content-analytical evaluation of the responses to the open-ended question "Please describe your work (e.g. voluntary, paid employment, social support of family or friends, other). Describe the main activity to which you wish to refer."Because of the qualitative nature of the data material, it was not possible to make an unambiguous distinction between paid and unpaid work. Künemund (2006: 116-121) also refers to the methodological problem in the delimitation between paid and unpaid work (see also Rosenbladt 2001: 216).

The respondents worked an average of 52.3 hours per week in their former professional positions $(S D=12.8)$. These numbers refer to the actual working hours, and ranged from 10 to 85 hours per week. Four out of five respondents $(80.3 \%)$ had worked more than 40 hours per week. For post-retirement activities, the working hours ranged between one and 60 hours per week, averaging out at 18.3 hours $(S D=12.3)$, which corresponds to roughly one third of the former hours per week. One third of respondents $(30.5 \%)$ worked for more than 20 hours per week in retirement.

The sample's high level of education corresponds to the complexity of the previous work. The activity currently carried out was established largely as a result of contacts from previous working life, through both external enquiries and following own initiative and active searches. One fifth of the respondents worked for commercial enterprises, but also for charitable, art and cultural institutions, as well as

Tab. 2: Clients of the study participants after retirement

\begin{tabular}{lc}
\hline Clients & Spread in the sample (\%) \\
\hline Private industry & 22.1 \\
Charities & 12.1 \\
Art and cultural institutions & 10.0 \\
Political institutions & 9.3 \\
Educational institutions & 8.6 \\
Rotary Club/Lions Club & 5.7 \\
Church institutions & 5.7 \\
Economic associations, clubs, and foundations & 5.0 \\
Sports clubs & 3.6 \\
Other & 17.9 \\
\hline
\end{tabular}

Note: $N=140$. Categorising responses to the open-ended question "Please describe your work (e.g. voluntary, paid employment, social support of family or friends, other). Describe the main activity to which you wish to refer."

Source: own design 
various associations. In our study, more than half of the retirees could benefit from skills acquired in their previous working lives. The sample is characterised by previous work that was intellectually demanding, a level that post-retirement activities cannot entirely sustain.

The results in the question areas described, namely transition into retirement, reasons and framework for post-retirement work, factors of work motivation, and physical and intellectual demands prior to and after retirement are presented in the following five sections. These results provide an overview of the relevant areas for an initial understanding of the life world of active retirees in Germany.

\subsubsection{Results: transition into retirement}

Three quarters of the respondents $(77.1 \%)$ stated in retrospect that they have fully achieved their professional goals. The average degree of achieving goals is 108.4 $(S D=27.4$; scale: $0-150)$. All in all, the work goals were fully achieved and were exceeded in some cases. More than half of the respondents $(52.2 \%)$ had entered retirement with positive feelings. Only $11.8 \%$ spoke of negative feelings in the transition into retirement. In an open-ended question about the reasons for retirement, four out of ten $(38.0 \%)$ respondents stated that it had been stipulated by company regulations. More than one quarter of the respondents $(26.8 \%)$ cited internal company reasons such as job cuts or even insolvency of the company as the reason for retirement. Only $12.7 \%$ mentioned health-related reasons leading to the termination of regular work. Looking back, the great majority of the respondents $(93.2 \%)$ would once again decide for the selected time of transition into retirement. Not all respondents retired of their own accord, but largely after a fulfilled working life and with positive feelings. Table 3 provides an overview of the development of postretirement activities.

One quarter of the unsupported statements $(24.1 \%)$ affirmed that post-retirement activity had been established on the basis of the previous work or contacts from working life. Nearly just as frequently $(23.6 \%)$, an external enquiry was named as leading to post-retirement activities. However, own initiative and active searching also accounts for one fifth $(19.7 \%)$ of the occurrences. Continuation and intensification of ancillary work or hobbies already pursued during working life determined one sixth $(15.8 \%)$ of the statements. The use of the individual's existing network, regardless of the former work, played a somewhat subordinate role $(7.4 \%)$, as did follow-on activities already pursued during working life $(2.5 \%)$ and the same activity on a different dimension $(2.5 \%)$. It should be taken into account here that multiple attributions were possible and that an individual's attributions could occur in various categories. When asked whether they had gained greater freedom in retirement, respondents reported considerably more freedom in retrospect: $79.7 \%$ responded positively to the question. Almost two thirds of them referred to gaining greater freedom as being indispensable $(61.8 \%)$. More than half of the skills $(56.5 \%)$ used in post-retirement work were identical to those used in their former work. The largest share of the respondents reported a flowing transition between 
Tab. 3: Development of post-retirement activities

\begin{tabular}{lc}
\hline Category & Occurrences (\%) \\
\hline From previous work, contact from job & 24.1 \\
External enquiry (passive) & 23.6 \\
Own initiative, active search & 19.7 \\
Continuation, intensification of work or hobbies & 15.8 \\
Contacts, network (not from old work) & 7.4 \\
Same work as before, different scale & 2.5 \\
Follow-on work was already decided on during working life & 2.5 \\
Other & 4.4 \\
\hline
\end{tabular}

Notes: Open-ended question: "How did you find your present work?" Multiple responses were possible. Content-analytical categorised fields. Krippendorff's $\alpha=0.69 . N=142.203$ occurrences. Occurrences stated as percentages.

Source: own design

leisure and work $(45.5 \%)$. One third $(33.6 \%)$ rigorously distinguished between the two areas. By contrast, one fifth did not distinguish between work and leisure at all (21.0\%).

\subsubsection{Results: reasons and framework}

Major aspects of taking up post-retirement activities are shown to be the areas of helping, the desire to pass on knowledge, wishing to remain active, own development, and contact with others. Table 4 provides an overview of the reasons, each of which were quantified in a content analysis and identified across different question areas. In two open-ended questions, a main general question was first asked about the reasons for post-retirement activities, and later in the course of the interview about aspects of post-retirement work that are particularly important to the respondent. Results of the two questions suggest that the category of wishing to help others and pass on knowledge is central. In the unstructured statements on the reasons for continuing in activities, it accounts for one eighth $(12.3 \%)$ of the occurrences, and for almost one third in the answers on importance $(30.5 \%)$. It is salient across both question areas in the category, indicating that it is a major element in the motivation for continuing to work. Another such element is contact with others, which is linked with post-retirement activities, with one sixth (16.7 \%) of occurrences regarding importance. A further fundamental component of the motivation for continuing activities is personal development and the desire to remain active, with more than one third (36.0\%) of occurrences regarding the reasons. Recognition and appreciation experienced through post-retirement activities are similarly frequent in both areas (reasons: $9.3 \%$, importance: $9.9 \%$ ), indicating that they are a further essential component of the motivation to engage in activities in retirement. Financial matters also appear within both the reasons for employment $(6.4 \%)$ and the 
Tab. 4: Reasons for post-retirement activities

\begin{tabular}{lcc}
\hline Reasons and importance & $\begin{array}{c}\text { Reasons }^{1} \\
\text { in percent }\end{array}$ & $\begin{array}{c}\text { Importance }^{2} \\
\text { in percent }\end{array}$ \\
\hline Helping, wanting to pass on knowledge & 12.3 & 30.5 \\
Contact with others & 7.6 & 16.7 \\
Wanting to remain active, personal development & 36.0 & 10.3 \\
Own demand, performance & -- & 10.3 \\
Recognition, appreciation & 9.3 & 9.9 \\
Fulfilment, well-being & -- & 8.9 \\
Financial reasons & 6.4 & 2.5 \\
Enjoyment, interest & 18.6 & -- \\
Other & 6.8 & 5.4 \\
Other contexts & 3.0 & 5.4 \\
\hline
\end{tabular}

Note: Content-analytical categorised fields. Information as a percentage of the occurrences. Open-ended questions:

1 "What reasons do you have for working in retirement?" ( $N=139 ; 236$ occurrences; Krippendorff's $\alpha=0.78$ )

2 "What is particularly important to you in your work?" ( $N=141 ; 203$ occurrences; Krippendorff's $\alpha=0.87$ )

Source: own design

important aspects of activity in retirement $(2.5 \%)$, albeit with a comparatively small number of occurrences. The topic of remuneration was named in the responses to both open-ended questions. Enjoyment and interest in the work were mentioned comparatively often among the reasons for post-retirement activities (18.6\%), but do not appear at all among important aspects of post-retirement work.

Table 5 sums up the results of the three open-ended questions on the ideal framework of post-retirement activities obtained by content analysis, the design of a specific personnel policy for older people, and in general on the areas with the greatest need for action for firms with regard to the employment of elderly people. In the overview of these open-ended questions, age-tailored working conditions and the consideration of specific needs, as well as recognition and appreciation, are shown to be promoted with different intensities. The salience of these categories is a clear indication that they are major structural elements in job design after retirement. These aspects are fundamental components of the design of post-retirement activities. The following are decisive across all three question areas: flexible working hour arrangements, age-tailored working conditions and the consideration of needs, and the use of experience-based knowledge in intergenerational exchange. The demand for flexible working hours is very dominant in the first two question areas on the ideal framework and specific personnel policy, with almost one third $(29.1 \%)$ and one eighth (12.8\%) of the occurrences, respectively, but is not regarded as constituting the greatest need for action on the part of organisations. Instead, 
Tab. 5: $\quad$ Framework for post-retirement activities

\begin{tabular}{|c|c|c|c|}
\hline Organisational framework & $\begin{array}{l}\text { Ideal in } \\
\text { retirement }\end{array}$ & $\begin{array}{l}\text { Personnel policy } \\
\text { for the elderly }\end{array}$ & $\begin{array}{l}\text { Need for firms } \\
\text { to take action }\end{array}$ \\
\hline Flexible working hours & 29.1 & 12.8 & -- \\
\hline Advisory, freelance work & 11.8 & -- & -- \\
\hline $\begin{array}{l}\text { Self-determination, freedom to make } \\
\text { decisions }\end{array}$ & 9.8 & -- & -- \\
\hline $\begin{array}{l}\text { Working conditions tailored to age, } \\
\text { consideration of needs }\end{array}$ & 7.2 & 18.3 & 11.9 \\
\hline Providing a structure & 5.6 & -- & -- \\
\hline Providing a meaning and a goal & 5.2 & -- & -- \\
\hline $\begin{array}{l}\text { Financial recognition, special } \\
\text { remuneration arrangements }\end{array}$ & 4.9 & -- & 2.0 \\
\hline Offering self-realisation & 4.6 & -- & -- \\
\hline Facilitating social contact & 4.2 & -- & -- \\
\hline No permanent job or employment & 4.2 & -- & -- \\
\hline Remaining active & 3.6 & -- & -- \\
\hline Recognition and appreciation & 2.3 & 8.5 & 23.8 \\
\hline Full-time, permanent post & 2.0 & -- & -- \\
\hline $\begin{array}{l}\text { Using experience and know-how, } \\
\text { exchange between young and old }\end{array}$ & -- & 15.2 & 29.1 \\
\hline Active involvement in the company & -- & 15.9 & 18.5 \\
\hline $\begin{array}{l}\text { Involvement in further and advanced } \\
\text { training }\end{array}$ & -- & 5.5 & 5.3 \\
\hline Specific services for elderly workers & -- & 10.4 & -- \\
\hline $\begin{array}{l}\text { Offering possibilities for flexible } \\
\text { retirement }\end{array}$ & -- & 7.9 & -- \\
\hline No special treatment & -- & 4.3 & 2.0 \\
\hline Changing state regulations & -- & -- & 3.3 \\
\hline Other & 5.6 & 1.2 & 4.0 \\
\hline
\end{tabular}

Notes: Content-analytical categorised fields. Information as a percentage of the occurrences. Open-ended questions:

1 "What would be the ideal conditions for work in retirement?" ( $N=141$; 306 occurrences; Despite a reduction in the complexity of the data it was not possible to calculate Krippendorff's a without combining the categories further, which would have entailed loss of content.)

2 "What should a specific personnel policy for elderly workers look like?" ( $N=111 ; 164$ occurrences; Krippendorff's $\alpha=0,67$ )

3 "Where do you see the greatest need for action for firms with regard to the employment of elderly people?" ( $N=120 ; 151$ occurrences; Krippendorff's $\alpha=0.71)$

Source: own design 
a change in state regulations is called for in the clustered responses to this question. Even though this category, identified by content analysis, is only slightly represented in the overview (3.3\% of occurrences of the question area), it nonetheless provides an indication of structural changes that employees would like to see for exercising their work when in retirement.

A large share of the occurrences in Table 5 stresses intergenerational exchange and passing on of knowledge as a major component, although the only statements quantified here were answers to questions on specific contents of a personnel policy for elderly employees and on locating the greatest need for action for organisations. Here, silver workers gave their personal retrospective accounts of the work situation prior to retirement. For post-retirement activities, it becomes clear that advisory, self-employed work is the goal, in which self-determination and freedom to take decisions are fundamental (altogether, $21.6 \%$ of the occurrences regarding the ideal framework of post-retirement activities). Aspects that were named across several question areas assume particular prevalence in the perception of the respondents. Financial remuneration of the contributions made by silver workers is named for both the desired framework $(4.9 \%)$ and the identified need for action $(2.0 \%)$. Even when, overall, a relatively small number of occurrences focus on this aspect, it is nonetheless worth noting that it turns up unprompted and independently in two question areas. The financial resources available to respondents appear to be an influencing element here. Moreover, a need for action on the part of the employing organisation in providing financial recognition was identified. Furthermore, remuneration is frequently regarded as constituting recognition of the contribution that has been made. From silver workers' perspective, the responsibility is definitely on companies at this juncture: The financial recognition of work in retirement does not always appear to be managed satisfactorily. Working retirees would also like organisations to involve them more in basic and further training and quite clearly consider the companies to be responsible for this: One out of 20 occurrences in the question areas on specific personnel policy for the elderly $(5.5 \%)$ and on greater need to act on the part of firms $(5.3 \%)$, respectively, call for including the elderly in further and advanced training. Some respondents called for equal treatment of all age groups in two question areas in unprompted statements (personnel policy: $4.3 \%$; need to act: $2.0 \%$ ). The two latter aspects, each occurring across different question areas, correspond with one another in terms of content: Treating elderly workers normally, that is, equally vis-à-vis workers of all age groups also encompasses inclusion in further and advanced training.

\subsubsection{Results: Factors of work motivation}

Skill variety, autonomy, and task significance as the selected factors of work motivation were assessed with regard to three different evaluation points. On a scale of 0 to 100 , the respondents categorized the current employment situation in retirement, a retrospective of the former work situation, and the ideal of post-retirement activities. Figure 3 shows the results for the dimensions with significant average value differences (t test for dependent samples; Bortz 1999: 140-142) between the three 
Fig. 3: Factors of work motivation in comparison

Mean values of the rating

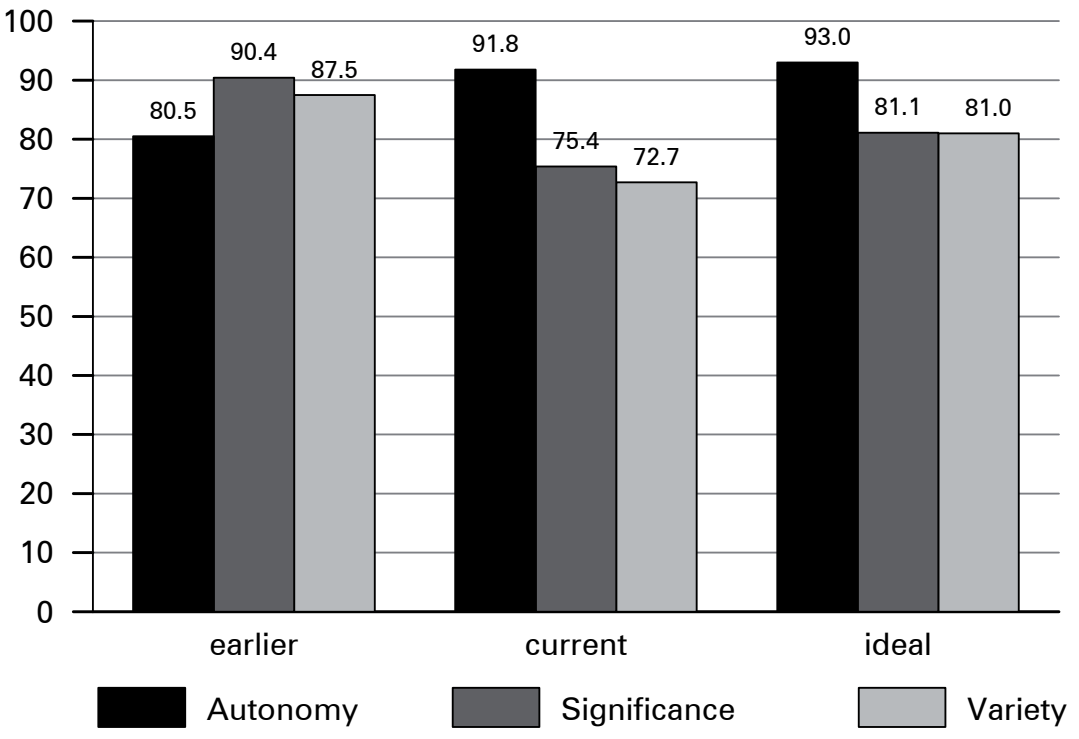

Notes: Attribution of selected factors of work motivation (Hackman/Oldham 1975; Oldham/Hackman 2010) at three different evaluation points: Prior to retirement (earlier), in active retirement (current), and in an ideal situation (ideal). Scale from 0-100 with the anchor values 0 -no occurrence, 50-medium level of occurrence, 100 -very high level of occurrence. $\mathrm{N}$ (autonomy earlier, current, ideal) $=144$. N (significance earlier) $=138 . \mathrm{N}$ (significance current) $=139 . \mathrm{N}$ (significance ideal) $=137 . \mathrm{N}$ (variety earlier) $=141 . \mathrm{N}$ (variety current) $=145$. $\mathrm{N}$ (variety ideal) $=144$. The mean values of the three assessments differ significantly from one another in each case, apart from the comparison autonomy current-ideal (t test for paired samples: $\mathrm{p}<0.001$ ).

Source: own design

evaluation points earlier, current, and ideal. Differences in the points are shown for the motivation factors skill variety, autonomy, and task significance. Two different courses are portrayed. For the dimensions task significance and skill variety, $\mathrm{v}$-shaped curves are shown with the highest peak for each in the previous work situation (significance: 90.4; $\mathrm{SD}=13.0$; significance earlier-current $\mathrm{t}=6.789, \mathrm{df}=135$, $\mathrm{p}<0.001$; variety: 87.5; $S D=14.5$; variety earlier-current $\mathrm{t}=7.471$, $\mathrm{df}=140, \mathrm{p}<0.001$ ). The tasks in current employment in retirement show a slighter degree of significance $(\mathrm{M}=75.4 ; \mathrm{SD}=24.3$; current-ideal $\mathrm{t}=-4.499, \mathrm{df}=135, \mathrm{p}<0.001)$ and variety $(\mathrm{M}=72.7$; $\mathrm{SD}=22.5$; current-ideal $\mathrm{t}=-5.816, \mathrm{df}=143 . \mathrm{p}<0.001)$, but have a much broader spread in comparison to variety. In an ideal situation, however, the respondents would again like to see a stronger manifestation of these two dimensions (significance: 81.1; $\mathrm{SD}=22.4$; significance earlier-ideal $\mathrm{t}=4.418, \mathrm{df}=133, \mathrm{p}<0.001$; variety: 81.0; $\mathrm{SD}=20.7$; variety earlier-ideal $\mathrm{t}=3.653, \mathrm{df}=139, \mathrm{p}<0.001$ ). For the motivation fac- 
tor autonomy, by contrast, a different course is revealed: Whereas for the work situation prior to retirement, with a broad spread overall, a much lower degree of autonomy is reported $(M=80.5 ; S D=22.0)$, the respondents reported a significant gain in autonomy for post-retirement activities $(M=91.8 ; S D=13.7$; earlier-current $t=-5.626, d f=143, p<0.001$ ), with a lowest rating of 40 . The degree of desired autonomy in an ideal situation achieves, with a very low spread, the highest value of all motivation factors $(M=93.0 ; S D=12.0$; earlier-ideal $t=-6.468, d f=143, p<0.001$ ) and does not significantly differ from the current situation. Here,50 was named by the respondents as the the lowest proficiency of the specified scale (0-100). For the job dimensions task identity and feedback, not portrayed in Figure 3, no significant average value differences are seen between the three evaluation points. The respectively highest value is shown for both motivation factors in analogy to autonomy in the ideal situation (task identity: 85.6; $S D=26.1$; feedback: $M=86.7 ; S D=19.3$ ). The values for the earlier and current employment situations are, however, below the mean values of the ideal situation (task identity earlier: $M=73.5 ; S D=32.3$; task identity current: $M=76.3$; $S D=33.5$; feedback earlier: $M=80.8 ; S D=18.9$; feedback current: $\mathrm{M}=79.9 ; \mathrm{SD}=23.5$ ).

\subsubsection{Results: Physical and intellectual demands}

In order to be able to assess the subjectively perceived demands of post-retirement activities in comparison to those of the earlier work situation and in an ideal situation (desired ideal), the respondents were asked to assess these on a scale of 0 to 100. Physical and intellectual demands were surveyed in an assessment of the current employment situation, of a retrospective of the earlier work situation, as well as of the ideal of post-retirement activity. Figure 4 shows the mean values of the rating of physical and intellectual demands for the three evaluation points. In each case they were assessed on a scale of 0 (no demands) to 100 (very high demands). Intellectual demands are highest in the earlier work situation, with a mean value of 87.2 $(S D=15.7)$; the lower bound is, remarkably, 40.Upon retirement, the respondents left behind an intellectually demanding activity. The lowest mean value $(M=69.7)$ and the highest standard deviation $(S D=23.9)$, with full use of the scale of intellectual demands, are shown for the employment situation in retirement, with the mean assessment still being high. The high level of variance provides an indication of the variety of design of the activities and inter-individual differences in retirement. In an ideal situation, taken as a mean value, the respondents would again like somewhat higher intellectual demands $(M=75.8 ; S D=21.7)$, but here too there are relatively significant differences between the respondents.

A similar distribution is shown in the assessment of the physical demands. In the earlier work situation these were comparatively highest, with a considerable spread $(M=67.0 ; S D=31.8)$, but lower than the lowest rating value of current intellectual demands. Physical demands in the post-retirement work situation were perceived as being lowest $(M=52.5 ; S D=26.0)$. And in an ideal situation, the respondents would wish for greater physical demands to be made on them $(M=57.5 ; S D=24.0)$. This median value lies between the earlier and current assessment. In the ratings of 
Fig. 4: Physical and intellectual demands in comparison

Mean values of the rating

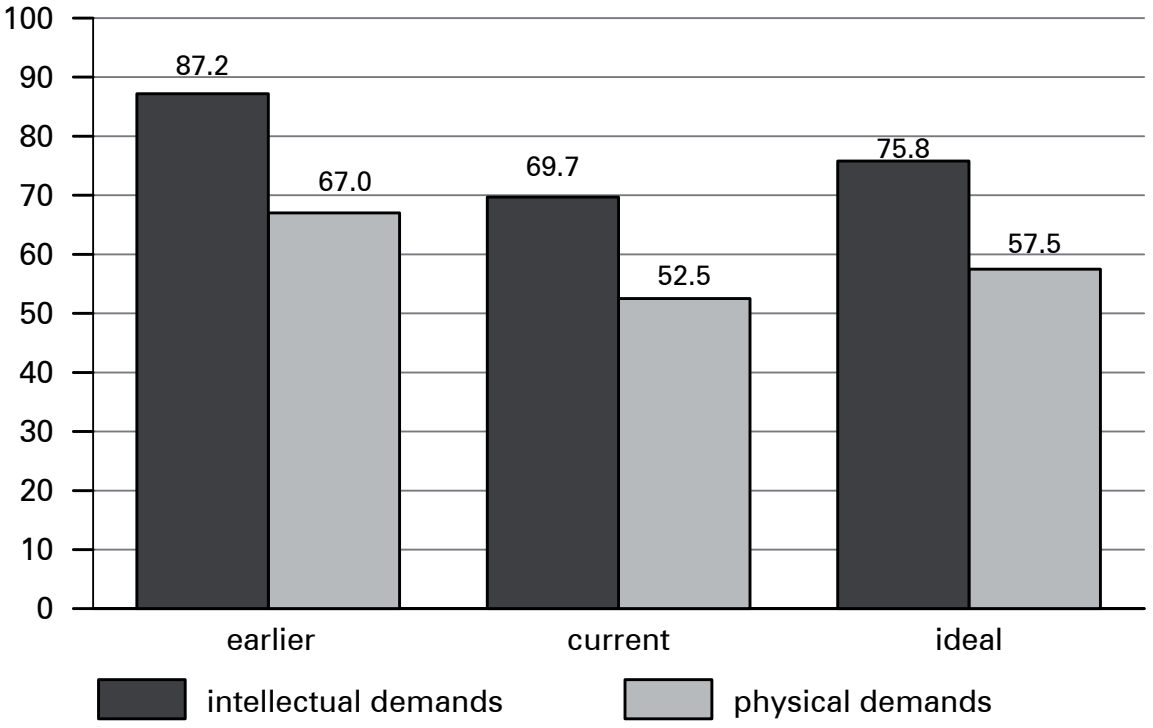

Notes: Attribution of intellectual and physical demands at three different evaluation points: Prior to retirement (earlier), in active retirement (current), and in an ideal situation (ideal) on a scale of 0-100 with the anchor values 0-no demands, 50-medium demands, 100 -very high demands. $\mathrm{N}$ (intellectual demands earlier) $=145$. N (intellectual demands current $)=145$. $\mathrm{N}$ (intellectual demands ideal) $=143 . \mathrm{N}$ (physical demands earlier $)=141 . \mathrm{N}$ (physical demands current) $=141 . \mathrm{N}$ (physical demands ideal) $=136$. The mean values of the three assessments in each case differ significantly from one another. $t$ test for paired samples: $p \leq 0.001$.

Source: own design

the physical demands, the scale from 0 to 100 was fully exhausted for each case. Stronger for intellectual demands, but also for physical ones, a V-shaped curve across the three evaluation points can be observed: The demands are lower in retirement in comparison to what they were earlier; in an ideal situation they would however be higher than they are currently. In each case, the mean values of the three evaluation points for intellectual and physical demands differ significantly from one another ( $t$ test for dependent samples: intellectual demands earlier-current $t=4.786$, $d f=140, p<0.001$; intellectual demands current-ideal $t=-3.358, d f=135, p \leq 0.001$; intellectual demands earlier-ideal $t=3.44, d f=134, p \leq 0.001$; physical demands earliercurrent $\mathrm{t}=7.651, \mathrm{df}=144, \mathrm{p}<0.001$; physical demands current-ideal $\mathrm{t}=-3.895, \mathrm{df}=134$, $p<0.001$; physical demands earlier-ideal $t=5.632, d f=142, p<0.001$ ). The interviewees desired a higher level of both intellectual and physical demands in retirement, albeit a lower level of physical than of intellectual demands.

The respondents stated on average that they wanted to keep on working up to the age of $73(\mathrm{M}=72.98, \mathrm{SD}=6.32 ; \mathrm{Md}=70.0 ; \mathrm{N}=42)$. The majority of silver workers 
$(30.2 \%)$ wanted to continue work until the age of 70 , while one seventh $(14.0 \%)$ wished to remain active until the age of 75 . One sixth of respondents $(16.3 \%)$ went so far as to express a desire to remain active until the age of 80 .

\section{Discussion and outlook}

The figures of the Federal Statistical Office demonstrate that paid employment clearly exists beyond the applicable retirement age. In view of the predictable demographic influences, this is already significant for the economic development of Germany today. In the future, the group of retirees will continue to grow in quantitative terms due to the baby boomer cohorts approaching retirement age. Given this, the number of working retirees can be expected to rise. However, against the background of the results that have been put forward, realizing the further potential of paid employment is contingent on relevant frameworks of work continuing to develop. As people grow older, the group of the self-employed and assistant family members will become more significant in relative terms while the total number of persons in paid employment at retirement age falls.

The motivations that have been identified through open-ended questions for post-retirement activities correspond in their content to the reasons for continuing to work in North America (AARP 2002; Atchley 1989; Dendinger et al. 2005; MorBarak 1995), although here an exemplary sample is used. Current research into work motivation advocates venturing to conduct "targeted research" in the field (Kanfer 2009: 89), that is, to conduct research into new phenomena in highly specific samples as well. Nonetheless, the initial empirical approach to the environment and working conditions of active retirees in Germany presented here has shortcomings. For one, the group surveyed here constitutes a fairly specific group of individuals who are far above the national average when it comes to educational status and financial situation. The addition of a control group, that is, of a survey of comparable retirees with differences in level of education, professional status, age, socio-economic status, and the like would have been desirable. Even so, this first empirical survey provides indications that the areas of work and leisure can no longer be kept strictly apart after retirement. Across different question areas, it becomes clear that the structure of silver workers' everyday life has changed after retirement. Whereas work activity, largely defined the day in regular working life, much more flexible structures are manifest in active retirement. This finding matches the assumptions of Kanfer that a much more flexible job design will be needed in the future in order to retain the elderly on the labour market and in companies (Kanfer 2009: 89). The frequently diverse activities of retirees are integrated in a variable, individual manner into leisure activities and family employment. This qualitative, overarching finding demonstrates the wide scope of action that silver workers make use of in their flexible framework conditions. At the same time, a connection can be observed here with the perceived finite nature of one's own life (socioemotional selectivity theory, Carstensen 2006). In the reasons for activity in retirement arising from open-ended questions in this empirical study, one can also observe that active retirees focus on 
meaningful activities linked with positive emotions, such as helping, wishing to pass on knowledge, and contact with others (see 2.2.6). This exemplary cross-sectional survey of a fairly homogeneous group cannot of course provide any information on the change of motives, but can provide an initial impression of relevant motives for work in retirement. The manifestation of motivation, however, also depends on other aspects, such as the design of the work. Flexibility and freedom are key elements here. Just as for elderly workers, the willingness of silver workers to continue activities is accompanied by a desire to considerably reduce their weekly working hours (see also Büsch et al. 2010a: 6). In this context, it is particularly important to make use of experience-based knowledge, while also taking individual needs into consideration. A lack of motivation to fully contribute in terms of performance at an advanced age (see Büsch et al. 2010b: 145) can also be traced back to the working conditions (see section 1.1). The results presented in this paper show that through the design of motivational work characteristic, active retirees can also contribute to the performance of organisations. The experience of autonomy, task identity, and feedback in post-professional job design is important, as is the freedom gained after the conclusion of a person's actual working life. Highly significant tasks and a wide variety of skills are factors that silver workers miss in post-retirement activities in comparison to their previous working lives. This suggests the necessity of attractive job design for retirees whose skills are in demand on the market. Kanfer (2009: 87) also pinpoints the development of motivation structures tailored to target groups of elderly workers whom organisations wish to help maintain a high level of motivation as a central challenge for applied research.

The representative questionnaire of the Federal Institute for Population Research revealed that persons currently in dependent employment wish to be employed for an average of another 4.1 years after the anticipated retirement age (Büsch et al. 2010b: 6). The retirees surveyed in the study presented here would indeed like to continue to work until the age of 73 on average. Under given preconditions, the motivation to continue post-retirement activities hence exists in principle. Furthermore, it is interesting to see that, despite the different social systems in Germany and North America, the results presented here point to considerable commonalities with the motivations identified in North America and the framework of post-retirement activities there (see Brown 2003; Calo 2005; Dendinger et al. 2005; Mor-Barak 1995).

\subsection{Derived need for research}

The field of post-retirement activities in Germany was described for the first time in the exploratory research project presented here. Relevant topical fields were identified. In future research on silver work, this first step, which constitutes a precursor to a hypothesis-generating research design, must be followed by a hypothesis-testing one that works with control group designs as well. The results reported here suggest that a comprehensive investigation of motivational job design may be worthwhile for the target group of silver workers. The "motivational work characteristics" observed in isolation in this paper (Hackman/Oldham 1975; 160-162; Morgeson/ 
Humphrey 2006: 1323) should be complemented by a comprehensive concept in which "knowledge characteristics" (Morgeson/Humphrey 2006: 1323), "social characteristics," and "contextual characteristics" (Morgeson/Humphrey 2006: 1324) are also considered. The "Work Design Questionnaire" (Morgeson/Humphrey 2006) offers itself for this purpose. Stegmann and colleagues (2010) provide a validated German translation. To record further interesting variables, validated scales for the relevant fields should be used, or new constructs and their operationalisations should be developed. For instance, it should be considered whether the construct space of "appreciation" can be adequately recorded with scales to measure the "respect" construct. A further interesting question is how the willingness to continue in employment and various forms of post-retirement activities is formed over time. To this end, a longitudinal design measuring motivation, socio-economic parameters, and willingness to contribute suggests itself, starting in the end phase of traditional working life and extending beyond retirement age.

Silver work continues to be a relevant field for work motivation research, largely - albeit not solely - inspired by demographic developments. For instance, future research should consider how age-related changes in the individual motivational preconditions, including physical and intellectual skills, personality characteristics, and demands outside the work situation influence the decision to continue to work (Kanfer 2009: 87). There is a considerable need for research on the willingness and motivation to continue employment in the production industries, so-called blue collar employment. The working conditions, differing considerably from employment in the white collar area (office jobs), make it likely that some major differences exist.

Self-employed persons and assistant family members are the decisive forms of employment in over-65 age group. Further research in the field of employment at retirement age should fully take into account the motivations of these two groups of individuals. This may lead to derivations being developed for other forms of postprofessional employment.

Previous findings on motivation to continue employment are either highly specific and restricted to a company or to a sector (Aleksandrowicz et al. 2009), thereby excluding relevant forms of employment such as self-employed persons (Büsch et al. 2010a), or are not representative of the population and are hence of only descriptive nature (the study presented here). To identify possible potentials, research findings the various forms of post-retirement activities must be applied to a larger, more representative population in future research.

\subsection{Concrete need to act at three levels}

Recommendations for action regarding the design and realisation of silver work can be derived at three levels from the presented results. The individual level deals with the physical and intellectual prerequisites of the individual, in this case of silver workers. This is worth examining from two perspectives:

1) Those interested in silver work create or maintain the individual prerequisites for an extension of their own active lifespan. 
2) Knowledge of the motives and demands of silver workers enables organisations to shape working conditions such that the well-being and job satisfaction of this group of individuals can be achieved. For the individual - regardless of age, given that each person in their mid-thirties today can be a potential silver worker one day - this implies a high degree of initiative, with measures such as further training, life-long learning, and healthcare spanning life phases.

These measures can clearly be supported in an appropriate manner at an organisational level, such as via corresponding offers in the framework of personnel development and values that are entrenched in the corporate culture. In concrete terms, the introduction and expansion of flexible working hours, advisory and freelance work, expansion of freedom to take decisions, appreciation of the contribution made by silver workers, benefiting from experience and know-how, adjusted workload and demands, a structured daily routine, active inclusion in events, and financial recognition lead to fruitful interaction between silver workers and organisations (see Deller/Maxin 2010a: 11). Central to this is cultural change in organisations towards a respectful, appreciative environment of younger and older staff members, as well as the use of synergies and acceptance of various careers. Perceptions and stereotypes of age are prevalent in many organisations, which generate antagonism more than collaboration between the generations. The concept of a life-phase-orientated personnel policy (see Rump et al. 2008: 22) takes account of the interplay between professional and private phases of life and their specific demands and of fields of action for organisations. In concrete terms, for instance, appreciation for all age groups in the company can be expressed with the aid of internal and external communication. Mentoring programs can encourage networking between elderly and younger workers in order to nurture mutual exchange and facilitate organisational learning. The introduction of diversity management (Köppel/Spie 2010) with an organisation-specific definition of success benchmarks or key performance indicators after each strategic goal can promote the sustainable development of the measures. The shaping of perceptions of age also plays a role at societal and political levels. The existing perception of age is undergoing change and appears to be turning slowly away from a negative picture that is based on the deficit model (BMFSFJ 2010). Age and productivity are no longer automatically contradictory in the societal discussion of old age, and awareness has arisen of its potentials. A differentiated perception of age can make a major contribution towards cultural change in society. For instance, there has recently been intensified public debate on the fact that if the statutory framework is made appropriately flexible, silver work can lead, firstly, to reducing the burden on the pension system. Secondly, the contributions made increasingly by senior citizens in voluntary work (see Alterssurvey 2002a: 3; Freiwilligensurvey 2006: 312) are becoming relevant to society. Reforms of many options for the transition from working life into retirement appear to be necessary. It is a matter of taking into account the changing prerequisites that increasingly differ from one individual to another. For individuals who work beyond the statutory retirement age and at the same time would like to pay social insurance contributions, a binding and appealing statutory basis for this possibility would be expedient. It should be definitive that employment is to meet the needs of people 
and should be shaped accordingly -regardless of age (see Deller/Maxin 2010b: 8). Clearly, the world of work can be expected to change. A job design that is adjusted to workers' needs can help today's 35-year-old workers want to become healthy, motivated silver workers.

\section{Acknowledgements}

We thank the editors of Comparative Population Studies and two anonymous reviewers for their helpful comments on an earlier version of this paper. We are indebted to Daniela Huch, Dr. Stefanie Plassmeier, and Dr. Konrad Reiher for their contributions to the qualitative study in 2005 and 2006.

\section{References}

AARP (American Association of Retired People) 2002: Staying Ahead of the Curve. The AARP Work and Career Study. Washington, DC: AARP.

Adams, Gary; Rau, Barbara 2004: Job Seeking Among Retirees Seeking Bridge Employment. In: Personnel Psychology 57: 719-744.

Aleksandrowicz, Paula et al. 2009: Die Bedeutung der Arbeit beim vorzeitigen Ausscheiden aus dem Arbeitsleben. In: Zeitschrift für Gerontologie und Geriatrie; Online First, 6. Oktober: 1-6 [doi: 10.1007/s00391-009-0068-y].

A/terssurvey 2002a: Tätigkeiten und Engagement in der zweiten Lebenshälfte. URL:http:// www.dza.de/nn_12036/SharedDocs/Publikationen/AS 2002 Presse Taetigkeite $\mathrm{n}$,templateld $=$ raw, property=publicationFile.pdf/AS_2002_Presse_Taetigkeiten.pdf, 17.8.2010.

Alterssurvey 2002b: Erwerbsbeteiligung und der Übergang in den Ruhestand. URL: http://www.dza.de/nn_12036/SharedDocs/Publikationen/AS_2002_Presse_Erwerb-Ruhestand, templateld=raw, property=publicationFile.pd $\bar{f} / \bar{A} S$ 200 $\overline{2}$ Presse-Erwerb-Ruhestand.pdf, 17.8.2010.

Aquino, Juan A. et al. 1996: Employment status, social support, and life satisfaction among the elderly. In: Journal of Counseling Psychology 43,4: 480-489 [doi: 10.1037/0022-0167.43.4.480].

Atchley, Robert C. 1989: A continuity theory of aging. In: The Gerontologist 29,2: 183-190.

Avolio, Bruce J.; Waldman, David A.; McDaniel, Michael A. 1990: Age and work performance in nonmanagerial jobs. The effects of experience and occupational type. In: Academy of Management Journal 33,2: 407-422 [doi: 10.2307/256331].

Baltes, Margret M.; Carstensen, Laura L. 1996: Gutes Leben im Alter. Überlegungen zu einem prozeßorientierten Metamodell erfolgreichen Alterns. In: Psychologische Rundschau 47,4: 199-215.

Baltes, Paul B. 1993: The aging mind. Potential and limits. In: Gerontologist 33,5: 580-594.

BAuA (Bundesanstalt für Arbeitsschutz und Arbeitsmedizin) 2008: Alles grau in grau? Ältere Arbeitnehmer und Büroarbeit. Dortmund: BAuA. 
Beehr, Terry A. 1986: The process of retirement. A review and recommendations for future investigation. In: Personnel Psychology 39,1: 31-55 [doi: 10.1111/j.1744-6570.1986. tb00573.x].

Beehr, Terry A.; Bennett, Misty M. 2007: Examining Retirement from a Multi-level Perspective. In: Shultz, Kenneth S.; Adams, Gary A. (Eds.): Aging and Work in the $21^{\text {st }}$ Century. Mahwah/New Jersey: Erlbaum: 277-302.

BMFSFJ (Bundesministerium für Familie, Senioren, Frauen und Jugend) 2010: Sechster Bericht zur Lage der älteren Generation in der Bundesrepublik Deutschland - Altersbilder in der Gesellschaft. Drucksache 17/3815. Berlin: BMFSFJ.

Börsch-Supan, Axel; Düzgün, Ismail; Weiss, Matthias 2009: Alter und Produktivität eine neue Sichtweise. In: Börsch-Supan, Axel et al. (Eds.): Produktivität in alternden Gesellschaften 4. Halle (Saale): Deutsche Akademie der Naturforscher Leopoldina: 53-62.

Bortz, Jürgen 1999: Statistik für Sozialwissenschaftler. $5^{\text {th }}$ edition. Heidelberg: Springer.

Brown, S. Kathi 2003: Staying ahead of the curve 2003. The AARP Working in Retirement Study. Washington, DC: AARP.

Brussig, Martin 2009: Die Erwerbsbeteiligung älterer Arbeitnehmer/-innen in Deutschland im Wandel. Perspektiven der Arbeitsmarktforschung. In: Zeitschrift für Gerontologie und Geriatrie 42,4: 281-286 [doi: 10.1007/s00391-009-0046-4].

Bundesinstitut für Bevölkerungsforschung 2008: Daten, Fakten, Trends zum demographischen Wandel in Deutschland. Wiesbaden: Bundesinstitut für Bevölkerungsforschung und Statistisches Bundesamt.

Büsch, Victoria et al. 2010a: Weiterbeschäftigung im Rentenalter. Wünsche - Bedingungen - Möglichkeiten. Materialien zur Bevölkerungswissenschaft 129. Wiesbaden: Bundesinstitut für Bevölkerungsforschung.

Büsch, Victoria; Dittrich, Dennis; Lieberum, Uta 2010b: Motivation älterer Arbeitnehmer. In: Salzmann, Thomas; Skirbekk, Vegard; Weiberg, Mirjam (Eds.): Wirtschaftspolitische Herausforderungen des demografischen Wandels. Berlin: VS Verlag für Sozialwissenschaften: 131-148.

Carstensen, Laura L. 2006: The Influence of a Sense of Time on Human Development. In: Science 312,5782: 1913-1915.

Calo, Thomas J. 2005: The generativitytrack. A transitional approach to retirement. In: Public Personnel Management 34,4: 301-312.

Collins, Gerald A. 2003: Rethinking Retirement in the Context of an Aging Workforce. In: Journal of Career Development 30,2: 145-157.

Craggs, Richard; Krippendorff, Klaus 2004: Measuring agreement between coders using multiple categories to describe units of observation. Unpublished manuscript.

Deller, Jürgen; Maxin, Leena 2008: „Silver Workers“ - Eine explorative Studie zu aktiven Rentnern in Deutschland. In: Arbeit 17,3: 166-179.

Deller, Jürgen; Maxin, Leena 2009: BeruflicheAktivitäten von Ruheständlern. In: Zeitschrift für Gerontologie und Geriatrie 42,4: 305-310 [doi: 10.1007/s00391-009-0047-3].

Deller, Jürgen; Maxin, Leena 2010a: Zukunft der Arbeit. In: Personal 6: 9-11.

Deller, Jürgen; Maxin, Leena 2010b: Silver Work. Zum Stand beruflicher Aktivitäten im Ruhestand in Deutschland. In: Informationsdienst Altersfragen 37,2: 3-9. 
Dendinger, Veronica M.; Adams, Gary A.; Jacobson, Jamie D. 2005: Reasons for working and their relationship to retirement attitudes, job satisfaction and occupational self-efficacy of bridge employees. In: International Journal of Aging and Human Development 61,1: 21-35 [doi: 10.2190/k8ku-46lh-dtw5-44tu].

Deutsche Rentenversicherung 2010: Rentenversicherung in Zahlen. Berlin: Deutsche Rentenversicherung.

Doeringer, Peter B. 1990: Economic Security, Labor Market Flexibility, and Bridges to Retirement. In: Doeringer, Peter B. (Eds.): Bridges to Retirement. Ithaca/NY: Cornell University: 3-32.

Feldman, Danie/ C. 1994: The Decision to Retire Early. A Review and Conceptualization. In: Academy of Management Review 19,2: 285-311 [doi: 10.2307/258706].

Feldman, Daniel C.; Kim, Seongsu 2000: Bridge employment during retirement. A field study of individual and organizational experiences with post-retirement employment. In: Human Resource Planning 23,1: 14-25.

Flick, Uwe 2008: Triangulation in der qualitativen Forschung. In: Flick, Uwe; von Kardorff, Ernst; Steinke, Ines (Eds.): Qualitative Forschung. Ein Handbuch. Reinbek: Rowohlt: 309-318.

Freiwilligensurvey 2006: Freiwilliges Engagement in Deutschland 1999-2004. Berlin: Bundesministerium für Familie, Senioren, Frauen und Jugend.

Giniger, Seymour; Dispenzieri, Angelo; Eisenberg, Joseph 1983: Age, experience and performance on speed and skill jobs in an applied setting. In: Journal of Applied Psychology 68,3: 469-475 [doi: 10.1037/0021-9010.68.3.469].

Gobeski, Kirsten T.; Beehr, Terry A. 2009: How Retirees Work. Predictors of Different Types of Bridge Employment. In: Journal of Organizational Behavior 30,3: 401-425 [doi: 10.1002/job.547].

Gramke, Kai et al. 2009: Arbeitslandschaft 2030. Auswirkungen der Wirtschafts- und Finanzkrise. München: Vereinigung der Bayerischen Wirtschaft e.V.

Griffin, Barbara; Hesketh, Beryl 2008: Post-retirement Work. The Individual Determinants of Paid and Volunteer Work. In: Journal of Occupational and Organizational Psychology 81,1: 101-121 [doi: 10.1348/096317907x202518].

Grube, Anna 2009: Alterseffekte auf die Bedeutung berufsbezogener Motive und die Zielorientierung. Diss. Westfälische Wilhelms-Universität zu Münster (Westf.).

Grube, Anna; Hertel, Guido 2008: Altersbedingte Unterschiede in Arbeitsmotivation, Arbeitszufriedenheit und emotionalem Erleben während der Arbeit. In: Wirtschaftspsychologie 10,3: 18-29.

Hackman, J. Richard; Oldham, Greg R. 1975: Development of the Job Diagnostic Survey. In: Journal of Applied Psychology 60,2: 159-170 [doi: 10.1037/h0076546].

Hertzog, Christopher et al. 2008: Enrichment effects on adult cognitive development. Can the functional capacity of older adults be preserved and enhanced? In: Psychological Science in the Public Interest 9,1: 1-65.

IImarinen, Juhani 2005: Towards a longer Worklife. Helsinki: Finnish Instiute of Occupational Health.

Kanfer, Ruth 2009: Work Motivation: Identifying Use-Inspired Research Directions. In: Industrial and Organizational Psychology 2: 77-93.

Kanfer, Ruth; Ackerman, Phillip L. 2004: Aging, Adult Development, and Work Motivation. In: Academy of Management Review 29,3: 440-458.

Köppel, Petra; Spie, Ulrich 2010: Vielfalt gewinnt. In: Personal 3: 38-41. 
Kolev, Vasil et al. 2009: Error-related oscillations. Effects of aging on neural systems for behavioral monitoring. In: Journal of Psychophysiology 23,4: 216-223 [doi: 10.1027/0269-8803.23.4.216].

Krippendorff, Klaus 2004: Reliability in Content Analysis. Some Common Misconceptions and Recommendations. In: Human Communication Research 30,3: 411-433 [doi: 10.1093/hcr/30.3.411].

Künemund, Harald 2006: Methodenkritische Anmerkungen zur Empirie ehrenamtlichen Engagements. In: Schroeter, Klaus R.; Zängl, Peter (Eds.): Altern und bürgerschaftliches Engagement. Wiesbaden: VS Verlag für Sozialwissenschaften: 111-134.

Landy, Frank J.; Conte, Jeffrey M. 2010: Work in the 21st Century. An Introduction to Industrial and Organizational Psychology. Hoboken/NJ: Wiley.

Lehr, Ursula 2007: Psychologie des Alterns. 11. Auflage. Wiebelsheim: Quelle \& Meyer.

Lehr, Ursula; Kruse, Andreas 2006: Verlängerung der Lebensarbeitszeit - eine realistische Perspektive? In: Zeitschrift für Arbeits- und Organisationspsychologie 50,4:240-247 [doi: 10.1026/0932-4089.50.4.240].

Lim, Ghee Soon; Ng, Lay Tin 1997: Early retirement and bridge employment intentions among older workers in Singapore. In: Asia Pacific Journal of Management 14,2: 185-210.

Matthews, Anne M.; Brown, Kathleen H. 1987: Retirement as a critical life event. The differential experiences of women and men. In: Research on Aging 9,4: 548-571 [doi: 10.1177/0164027587094004].

Mayring, Philipp 2000: Pensionierung als Krise oder Glücksgewinn? Ergebnisse aus einer quantitativ-qualitativen Längsschnittuntersuchung. In: Zeitschrift für Gerontologie und Geriatrie 33,2: 124-133 [doi: 10.1007/s003910050168].

Mayring, Philipp 2008: Qualitative Inhaltsanalyse. $10^{\text {th }}$ edition. Weinheim: Beltz.

McEnrue, Mary P. 1988: Length of experience and the performance of managers in the establishment phase of their careers. In: Academy of Management Journal 31,1: 175-185 [doi: 10.2307/256504].

Moog, Stefan; Raffelhüschen, Bernd 2010: Herausforderungen der Legislaturperiode für die Tragfähigkeit der Renten- und Pflegeversicherung. Vierteljahrshefte zur Wirtschaftsforschung 79,1: 27-43.

Mor-Barak, Michàl E. 1995: The meaning of work for older adults seeking employment. The generativity factor. In: The International Journal of Aging and Human Development 41,4: 325-344.

Morgeson, Frederick P.; Humphrey, Stephen E. 2006: The Work Design Questionnaire (WDQ): Developing and validating a comprehensive measure for assessing job design and the nature of work. In: Journal of Applied Psychology 91,6: 1321-1339 [doi: 10.1037/0021-9010.91.6.1321]

Naegele, Gerhard; Sporket, Mirko 2009: Altern in der Arbeitswelt. In: Zeitschrift für Gerontologie und Geriatrie 42,4: 279-280 [doi: 10.1007/s00391-009-0053-5].

Neuendorf, Kimberly A. 2002: The Content Analysis Guidebook. Thousand Oaks, CA: Sage.

Oldham, Greg R.; Hackman, J. Richard 2010: Relationships between organizational structure and employee reactions. Comparing alternative frameworks. In: Administrative Science Quarterly 26,1: 66-83 [doi: 10.2307/2392600].

Pleau, Robin L. 2010: Gender Differences in Postretirement Employment. In: Research on Aging 32,2: 267-303 [doi: 10.1177/0164027509357706]. 
Quiñones, Miguel A.; Ford, J. Kevin; Teachout, Mark S. 1995: The relationship between work experience and job performance. A meta-analytic review. In: Personnel Psychology 48,4: 887-910 [doi: 10.1111/j.1744-6570.1995.tb01785.x].

Reday-Mulvey, Geneviève 2005: Working beyond 60. Key policies and practices in Europe. New York: Palgrave Macmillan.

Rosenbladt, Bernhard von 2001 (Eds.): Freiwilliges Engagement in Deutschland. Ergebnisse der Repräsentativerhebung 1999 zu Ehrenamt, Freiwilligenarbeit und bürgerschaftlichem Engagement. Stuttgart: Kohlhammer.

Rump, Jutta; Eilers, Silke; Groh, Sibylle 2008: Lebensphasenorientierte Personalpolitik. Strategie für die Zukunft. Ein Leitfaden für Unternehmen zur Bindung und Gewinnung von Mitarbeiterinnen und Mitarbeitern. Mainz: MWVLW und MASGFF RheinlandPfalz.

Saba, Tania; Guerin, Gilles 2005: Extending employment beyond retirement age: The case of health care managers in Quebec. In: Public Personnel Management 34,2: 195-214.

Salthouse, Timothy A. 1984: Effects of age and skill in typing. In: Journal of Experimental Psychology 113,3: 345-371 [doi: 10.1037/0096-3445.113.3.345].

Schooler, Carmi 1999: The workplace environment: Measurement, psychological effects, basic issues. In: Friedman, Sarah L.; Wachs, Theodore E. (Eds.): Measurement of Environment Across the Life Span. Hyattsville, MD: American Psychological Association Press: 229-246.

Schooler, Carmi; Mulatu, Mesfin Samuel 2001: Reciprocal effects of leisure time activities and intellectual functioning in older people: a longitudinal analysis. In: Psychology and Aging 16,3: 466-482.

Schooler, Carmi; Mulatu, Mesfin Samuel; Oates, Gary 1999: The continuing effects of substantively complex work on the intellectual functioning of older workers. In: Psychology and Aging 14: 483-506.

Shultz, Kenneth S. 2001: The New Contingent Workforce. Examining The Bridge Employment Options of Mature Workers. In: International Journal of Organization Theory and Behavior 4,3/4: 247-258.

Shultz, Kenneth S.; Wang, Mo 2011: The Changing Nature of Retirement. In: American Psychologist; Online First, 24. Februar: 1-10. [doi: 10.1037/a0022411]

Skirbekk, Vegard 2008: Age and Productivity Capacity: Descriptions, Causes and Policy Options. In: Ageing Horizons 8: 4-12.

Spiegel Online (Yasmin El-Sharif) 2010: Debatte um Rente mit 67. Malochen, solange der Rücken hält. In: spiegel.de 10.8.2010. URL: http://www.spiegel.de/wirtschaft/soziales/0,1518,711094,00.html, 11.8.2010.

Stamov-Roßnagel, Christian; Hertel, Guido 2010: Older workers' motivation. Against the myth of general decline. In: Management Decision 48,6: 894-906 [doi: 10.1108/00251741011053451].

Statistisches Bundesamt 2009a: Tabelle: Bevölkerung - darunter Ausländer - nach Alter, Beteiligung am Erwerbsleben sowie Erwerbstätige nach Stellung im Beruf für die Jahre 1997, 2002 und 2007. Written message by the Federal Statistical Office.

Statistisches Bundesamt 2009b: Statistik von A - Z Mikrozensus. Statistisches Bundesamt. URL: http://www.destatis.de/jetspeed/portal/cms/Sites/destatis/Internet/DE/ Presse/abisz/Mikrozensus, templateld=renderPrint.psml, 17.8.2010. 
Staudinger, Ursula M. 1996: Psychologische Produktivität und Selbstentfaltung im Alter. In: Baltes, Margret M.; Montada, Leo (Eds.): Produktives Leben im Alter. Frankfurt a. M.: Campus: 344-373.

Staudinger, Ursula M.; Baltes, Paul B. 1996: Weisheit als Gegenstand psychologischer Forschung. In: Psychologische Rundschau 47,2: 1-21.

Stegmann, Sebastian et al. 2010: The Work Design Questionnaire - Introduction and validation of a German version. In: Zeitschrift für Arbeits- und Organisationspsychologie 54,1: 1-28.

Ulrich, Lorene B.; Brott, Pamelia E. 2005: Older workers and bridge employment. Redefining retirement. In: Journal of Employment Counseling 42,4: 159-170.

Wang, Mo; Shultz, Kenneth S. 2010: Employee Retirement. A Review and Recommendations for Future Investigation. In: Journal of Management 36,1: 172-206 [doi: 10.1177/0149206309347957].

Wang, Mo et al. 2008: Antecedents of bridge employment. A longitudinal investigation. In: Journal of Applied Psychology 93,4: 818-830 [doi: 10.1037/0021-9010.93.4.818].

Weckerle, Joelle R.; Shultz, Kenneth S. 1999: Influences on the bridge employment decision among older USA workers. In: Journal of Occupational and Organizational Psychology 72,3: 317-329 [doi: 10.1348/096317999166707].

Wild-Wall, Nele; Gajewski, Patrick; Falkenstein, Michael 2009: Kognitive Leistungsfähigkeit älterer Arbeitnehmer. In: Zeitschrift für Gerontologie und Geriatrie 42,4: 299-304 [doi: 10.1007/s00391-009-0045-5].

Yordanova, Juliana et al. 2004: Sensorimotor slowing with ageing is mediated by a functional dysregulation of motor-generation processes. Evidence from high-resolution event-related potentials. In: Brain. A Journal of Neurology 127,2: 351-362 [doi: 10.1093/ brain/awh042].

Translated from the original text by the Federal Institute for Population Research, for information only. The reviewed and author's authorised original article in German is available under the title "Beschäftigung statt Ruhestand: Individuelles Erleben von Silver Work", DOI 10.4232/10.CPoS2010-18de or URN urn:nbn:de:bib-cpos-2010-18de5, at http://www.comparativepopulationstudies.de.

Date of submission: 31.08 .2010

Date of Acceptance: 27.06 .2011

Leena Maxin ( $\varangle)$, Prof. Dr. Jürgen Deller. Institut für Strategisches Personalmanagement, Leuphana Universität Lüneburg, 21335 Lüneburg, Germany and Silver Workers Institute, Genf, Switzerland.

E-Mail: maxin@leuphana.de,deller@leuphana.de

URL: www.leuphana.de/institute/ispm, www.silverworkers.ch 


\section{Comparative Population Studies - Zeitschrift für Bevölkerungswissenschaft}

wWw.comparativepopulationstudies.de

ISSN: 1869-8980 (Print) - 1869-8999 (Internet)

Published by / Herausgegeben von

Prof. Dr. Norbert F. Schneider

Layout and print: Federal Institute for Population Research, Wiesbaden (Germany)

Managing Editor / Redaktion

Frank Swiaczny

\section{Copy Editor / Schlussredaktion}

Dr. Evelyn Grünheid

\section{Scientific Advisory Board / Wissenschaftlicher Beirat}

Jürgen Dorbritz (Wiesbaden)

Paul Gans (Mannheim)

Johannes Huinink (Bremen)

Marc Luy (Wien)

Clara H. Mulder (Groningen)

Notburga Ott (Bochum)

Peter Preisendörfer (Mainz)

\section{Board of Reviewers / Gutachterbeirat}

Martin Abraham (Erlangen)

Laura Bernardi (Lausanne)

Hansjörg Bucher (Bonn)

Claudia Diehl (Göttingen)

Andreas Diekmann (Zürich)

Gabriele Doblhammer-Reiter (Rostock)

Henriette Engelhardt-Wölfler (Bamberg)

E.-Jürgen Flöthmann (Bielefeld)

Alexia Fürnkranz-Prskawetz (Wien)

Beat Fux (Zürich)

Joshua Goldstein (Rostock)

Karsten Hank (Köln)

Sonja Haug (Regensburg)

Franz-Josef Kemper (Berlin)

Michaela Kreyenfeld (Rostock)

Aart C. Liefbroer (Den Haag)

Kurt Lüscher (Konstanz)

Dimiter Philipov (Wien)

Tomáš Sobotka (Wien)

Heike Trappe (Rostock) 